\title{
American Catholic Press: From Isolationism to Militant Anti-Communism, 1939-1945
}

\author{
Gregory L. Freeze ${ }^{1,2}$
}

The archives of the Catholic News Agency (CNA) shed valuable light on the transition of American Catholics from antiwar isolationists to militant anticommunists. Until December 1941 most Catholics opposed American intervention in the European military conflict, but after the Japanese attack on Pearl Harbor they patriotically supported American troops and silently tolerated the alliance with the Soviet Union. But from the spring of 1943 American Catholics began to speak out openly against the communist ally. The news feeds from CNA shed light on this transformation: they underscore the role of religion (and especially the role of religious repression) in international relations, which to a significant degree explain the shift in Soviet religious policy during the war. The CNA archives also show how ineffective, or even counterproductive, was Moscow's religious policy on the diplomatic front, above all with regard to Catholics. This article also offers a new perspective on the so-called "silence" of Pope Pius XII - his refusal to name specific countries as perpetrators of war crimes, his willingness to speak only in abstract terms. CNA in effect served as his surrogate: it expressed what the pope himself could not publicly say without violating his neutrality.

Keywords: Roman-Catholic Church, Soviet Union, World War II, religious repression, anticommunism, American Catholics.

Relationship and Activities. This article is part of a project supported by the Russian Science Foundation (No. 19-18-00482), "Entangled Histories: Russia and the Holy See, 1917-1958".

${ }^{1}$ Brandeis University, Waltham, MA, United States; ${ }^{2}$ Institute of World History of the Russian Academy of Sciences, Moscow, Russia.

Gregory L. Freeze, historian, specialist in the history of the Russian Church, Professor at Brandeis University, researcher at the Institute of General History of the Russian Academy of Sciences. Special interests - History of Russia, history of the Russian Church, social history, history of everyday life. ResearcherID: AAV-1601-2020, ORCID: 0000-0003-2831-336X.

Corresponding author: freeze@brandeis.edu

Received: 05.10.2021

Revision Received: 12.11 .2021

Accepted: 10.12 .2021

For citation: Gregory L. Freeze. American Catholic Press: From Isolationism to Militant Anti-Communism, 19391945. Russian Journal of Church History. 2021;2(4):5-25. (In Russ.) doi:10.15829/2686-973X-2021-72 


\title{
Американская католическая пресса: от изоляционизма к воинствующему антикоммунизму
}

\author{
Грегори Ли Фриз ${ }^{1,2}$
}

\begin{abstract}
Архивы Католического агентства новостей (КАН) показывают эволюцию взглядов католиков в США от антивоенного изоляционизма к воинствующему антикоммунизму. До 1941 г. большинство католиков в США противостояло вмешательству в европейский военный конфликт, а после нападения Японии на Пёрл-Харбор они патриотически поддержали американские войска и молчаливо согласились на союз с СССР. Однако с весны 1943 г. американские католики стали открыто выступать против коммунистического союзника. Сообщения КАН отражают эту эволюцию. Материалы КАН показывает роль религиозного фактора (и особенно роль религиозных репрессий) в международных отношениях, что во многом объясняет и изменение в советской религиозной политике во время войны. Но архивы КАН также показывают, насколько неэффективно, или даже контрпродуктивно, советская власть вела свою религиозную политику на дипломатическом фронте, прежде всего относительно католиков. Статья также предлагает новый взгляд на так называемое молчание папы Пия XII, в частности на его отказ назвать конкретные страны в качестве виновников военных преступлений, его готовность высказываться только абстрактно. КАН по сути дела служило его замещением: оно выражало то что папа сам не смог публично сказать, не нарушая своего нейтралитета.
\end{abstract}

Ключевые слова: Римско-католическая церковь, Советский Союз, Вторая мировая война, антикоммунизм, американские католики.

Отношения и деятельность. Данная статья подготовлена в рамках проекта, поддержанного РНФ (№19-1800482) "Entangled Histories: Россия и Ватикан, 1917-1958 гг.".

'Brandeis University, Waltham, MA, United States; ${ }^{2}$ Институт всеобщей истории Российской академии наук, Москва, Россия.

Грегори Ли Фриз - историк-русист, специалист в области истории Русской церкви, профессор Брандейского университета, научный сотрудник Института всеобщей истории Российской академии наук. Сфера научных интересов: История России, история Русской церкви, социальная история, история повседневности. ResearcherID: AAV-1601-2020, ORCID: 0000-0003-2831-336X.

Автор, ответственный за переписку (Corresponding author): freeze@brandeis.edu

Рукопись получена 05.10.2021

Рецензия получена 12.11 .2021

Принята к публикации 10.12.2021

Для цитирования: Грегори Ли Фриз. Американская католическая пресса: от изоляционизма к воинствующему антикоммунизму. Российский журнал истории Церкви. 2021;2(4):5-25. doi:10.15829/2686-973Х-2021-72

Catholics represented a significant political force in American politics. As their numbers increased between the First and Second World Wars ${ }^{1}$, they constituted the single largest confession in the country (comprising 36 percent

1 Between 1920 and 1945 the Catholic population in America increased from 17.7 million to 23.9 million (35 percent). The number of Catholic clergy increased at an ever higher rate - from 21,019 to 38,451 (82 percent), reflecting the continuing strength and appeal of the Church. Carey, P. W. (2004). Catholics in America. A History. Westport, 79. Текст печатается в авторской редакции. 
of all registered believers) ${ }^{2}$. Despite the tradition of anti-Catholicism ${ }^{3}$, Protestant political elites were very attentive to the Catholic voting bloc; that was especially true of the Democratic Party - for which Catholics voted in overwhelming numbers ${ }^{4}$. Franklin D. Roosevelt, an Episcopalian but politically savvy, was careful to cater to the Catholic electorate ${ }^{5}$. Although limited to a personal representative (not an ambassador) at the Vatican, Roosevelt worked behind the scenes to win papal support for his campaign to transform American Catholics from diehard isolationists into patriotic supporters of intervention in the European conflict. But anticommunism remained deeply embedded in the views of most Catholics and indeed resurfaced midway through the war.

The scholarship on wartime diplomacy is prodigious but has focused on the high politics (the Vatican and its relationship to the Allied and Axis powers) ${ }^{6}$. Far less attention has been given to Catholic public opinion. Although American scholarship has been archivally intensive and illuminating, it has done little to cast light on the Catholic media that shaped Catholic attitudes toward the hot-button issues of war and peace.

To fill that gap in the scholarship, this study examines the "news feeds" of the Catholic News Agency (CNA). Established in 1920 as a department in the National Catholic Welfare Council $(\mathrm{NCWC})^{7}$, this news agency collected and

2 Bureau of the Census (1941). Religious Bodies 1936: Selected Statistics. Washington D.C., 40.

3 For a recent overview, see: Massa, M. (2003). Anti-Catholicism in America: The Last Acceptable Prejudice. New York. For a broader treatment, see: European Anti-Catholicism in Comparative and Transnational Perspective (2013). Werner, Y. and Harvard, J., eds. Amsterdam; Roulin, S., van Dongen L. and Scott-Smith G. (2014). Transnational Anticommunism and the Cold War: Agents, Activities, Networks. New York; Kirby, D. (2013). The Religious Cold War. Oxford Handbook of the Cold War. Ed. R. Immerman and Peter Goedde. Oxford, 540-564.

4 Indeed, they voted for Democrats at a disproportionately higher rate than did Protestants. According to some surveys, they were 27 to 31 percent more likely to vote Democrat than their Protestant countrymen. Carey, P. W. (2004). Catholics in America. A History. Westport, 88. See also: Sirgiovanni, G. (1990). An Undercurrent of Suspicion: Anti-Communism and Anti-Soviet Opinion in World War II America. New Brunswick.

5 For well-informed overviews, see: Barone, M. (2003). Franklin D. Roosevelt: A Protestant Patrician in a Catholic Party. FDR, the Vatican, and the Roman Catholic Church in America, 1933-1945. ed. David Woolner and Richard Kurial. New York, 3-10; Fogarty, G. (2003). Roosevelt and the American Catholic Hierarchy. FDR, the Vatican, and the Roman Catholic Church in America, 1933-1945. ed. David Woolner and Richard Kurial. New York: Palgrave Macmillan, 11-43. After the war, Roosevelt's special emissary published the correspondence between the president and pope: Wartime Correspondence between President Roosevelt and Pope Pius XII (1947). Taylor, M., ed. New York.

6 By contrast, the scholarship on Soviet religious policy during the war is immense, consisting of both documentary publications and scholarly monographs. Excellent examples include: Васильева, О. Ю. (2001). Русская православная церковь и политика советского государства в 1943-1948 гг. М.; Шкаровский, М. В. (1999). Русская православная церковь при Сталине и Хрущеве. М.; Одинцов, М. И. (2005). Власть и религия в годы войны. М.; Русская православная церковь в годы Великой отечественной войны 1941-1945 гг. (2009). Васильева, О. Ю., Кудрявцев, И. И., Лыкова, Л. А., ред. Сборник документов. М.

7 The NCWC began as an episcopal organ during World War I, with the task of mobilizing support and resources for American armed forces. Established in 1917, it was the first collective episcopal organ since 1884 and attracted scores of bishops and religious organizations to its first meeting. After the war it shifted the focus to issues like prohibition and parochial schools, but soon encountered opposition from Rome: the Holy See feared a resurgence of "Americanism" - demands that American Catholicism be allowed to follow its own needs and adapt to the special circumstances of the New World. Influential prelates eventually persuaded the Vatican to relent, enabling NCWC to become the principal voice for American Catholicism. It also established a Press and Publicity Department, which became the organizational basis of the Catholic News Agency. For a richly detailed account of NCWC and its leadership, see Boyea, E. (1987). The National Catholic Welfare Conference: An Experience 
disseminated reports about Catholics around the world and worked to overcome the narrow parochialism of most Catholic journals and diocesan newspapers. And that Catholic press had enormous influence, with a wartime circulation of approximately 9 million subscribers ${ }^{8}$. Relying on dispatches from its own incountry correspondents and from other newspapers and radio broadcasts, CNA sent weekly "news feeds" to a plethora of Catholic papers in America as well as to some abroad. Prior to World War II, CNA provided substantial coverage of the Soviet Union: despite the downturn in Soviet-Catholic relations from the late 1920s, CNA reporting on the Stalinist antireligious campaign served to fuel a deepening anticommunist sentiment.

\section{Problems of Wartime Journalism}

World War II, however, posed a major challenge to CNA's capacity to gather news, especially from Eastern Europe and the Soviet Union. A month after the outbreak of the war, Frank Hall (director of CNA) described the agency's plight in a letter to its correspondent in France: "With the German occupation or threat in central Europe, we find correspondents of ours in some countries either eliminated or handicapped." At this point, he emphasized, CNA was keen to obtain information through "articles and publications, refugees, or travelers" 9 He certainly did not exaggerate the difficulties. The long-term correspondent in Vienna, Dr. Friedrich Funder, was arrested and sent to Dachau shortly after the Anschluss (German annexation of Austria) in March $1938^{10}$. CNA also lost its Paris correspondent of twenty years who had been "called to colors". In October 1939 Hall hastily sought to train a replacement who could serve CNA's Catholic readership. He instructed the new correspondent to avoid dispatches on military questions or "the progress of the war". Instead, Hall emphasized that "we are much interested in developments relating to communism, a power which has as a leading purpose the elimination of religion" 1 . Even when CNA had correspondents in Europe, communications proved increasingly difficult; diplomats complained that it took a full seven days for a dispatch to go from Rome (via Switzerland) to Washington, and the time required steadily increased ${ }^{12}$. In the "fog" of war, compounded by deliberate disinformation, it was exceedingly

in Episcopal Leadership, 1935-1945. Ph.D. diss. Catholic University of America. See also Fogarty, G. (1985). The Vatican and the American Hierarchy from 1870 to 1965. Wilmington.

8 Sirgiovanni, G. (1990). An Undercurrent of Suspicion: Anti-Communism and Anti-Soviet Opinion in World War II America. New Brunswick, 241-242.

9 Catholic University of America [hereafter CUA], Collection 10, Box 18, file 7, unpaginated (Frank Hall to M. Massiani, 6.X.1939).

10 Funder began serving as a correspondent in 1920 and over the next eighteen years submitted 741 dispatches (the last on 19 March 1938), shortly after the Anschluss (12 March) and before the Nazi confiscation of all Catholic media in Austria (28 March 1938). CNA's Paris correspondent, M. Massiani, reported in a letter of August 1938 that Funder had been arrested and had appeared in a photograph from Dachau. CUA, Collection 10, Box 18, File 18, unpaginated (M. Massiani to [Hall], 15.VIII.1938).

11 CUA, Collection 10, Box 18, file 7, unpaginated (Frank Hall to Paul de la Borie, 6.X.1939).

12 Inside the Vatican of Pius XII; the Memoirs of an American Diplomat during World War II (2004). Tillmann, H., ed. New York, 85. On the delays in communications to the Vatican (up to 5 months for a dispatch from Slovakia to Rome), see Alvarez, D. and Graham R. (1997). Nothing Sacred: Nazi Espionage against the Vatican, 19391945. London: Frank Cass, 145. 
difficult to assess the accuracy of reports, whether from combatants or neutral parties $^{13}$.

CNA experienced a sharp decrease in reports, especially after the German invasion of the Soviet Union on 22 June 1941. Measured by the citations in CNA news feeds, between 1939 and 1942 references to European countries dropped 59 percent and even more in the case of Russia (69 percent). Having reached bottom in 1942, CNA slowly returned to prewar levels: between 1942 and 1945 dispatches increased for European countries (62 percent) and still more for Russia (72 percent).

\section{Country References in CNA News Feeds}

\begin{tabular}{|l|l|l|l|}
\hline Country & 1939 & 1942 & 1945 \\
\hline England & 231 & 135 & 246 \\
\hline France & 346 & 113 & 350 \\
\hline Germany & 393 & 132 & 520 \\
\hline Italy & 300 & 102 & 392 \\
\hline Poland & 231 & 127 & 378 \\
\hline Russia & 222 & 68 & 244 \\
\hline Vatican & 699 & 355 & 606 \\
\hline Total & 2,422 & 1,032 & 2,736 \\
\hline
\end{tabular}

The decline was not only quantitative, but also qualitative: CNA had to rely on second-hand reports, often of dubious accuracy. In the case of Russia, CNA received its last in-country report on 11 November $1940^{14}$. Thereafter CNA carried reports about antireligious campaigns and repression in the occupied territories, with virtually nothing about the situation in Russia itself. Nor did the dispatches meet Hall's requirement of accuracy. The most famous failure was the reliance on Monsignor Enrico Pucci ${ }^{15}$. A long-standing CNA correspondent (filing his first dispatch on 25 October 1920), Pucci claimed to be a semi-official press agent for the Holy See and even had a tiny office on Vatican premises. Over the next twenty-two years he filed 3,405 dispatches, with a peak of 363 in 1941. But the various news agencies that employed him (including the New York Times) became increasingly suspicious when his postings proved false and in early 1942 terminated contact. So too did CNA, with Pucci's last dispatch appearing on 19 January 1942. It later turned out that Pucci was also in the employ of the German and Italian secret services, operating as one of their "moles" in the Vatican. Pucci was not the only source of fake news. No less infamous was Virgilio Scattolini, who managed to bamboozle America's wartime intelligence agency

${ }_{13}$ On wartime propaganda see the observations by Robert Graham, one of the editors of the classic twelve-volume set of documents on the Vatican in World War II: Graham, R. (1996). The Vatican and Communism during World War. San Francisco, 107-120

14 Until that last dispatch CNA still carried some reports about Soviet antireligious policy and the resistance of believers in Russia itself. In 1939, for example, CNA distributed reports from Moscow about an underground convent in Moscow. CNA 29.IV.1939, P, 5 (Moscow, 24.IV.1939). Another dispatch from the capital in June describes the dissemination of anonymous letters with extensive Biblical quotations. CNA, 12.VI.1939, P. 52 (Moscow, 5.V.1939).

15 Alvarez, D. (2002). Spies in the Vatican. Espionage \& Intrigue from Napoleon to Holocaust. Lawrence, Kansas, 156-157; Alvarez, D. and Graham R. (1997). Nothing Sacred: Nazi Espionage against the Vatican, 1939-1945. London: Frank Cass. 
(Office of Strategic Services) and drew a handsome monthly income of $\$ 500$ for fake news before he was finally exposed and dismissed ${ }^{16}$.

For lack of regular correspondents in most of Europe, CNA had to rely upon a hodgepodge of sources. Particularly prominent was the semi-official newspaper of the Vatican, L'Osservatore Romano, as well as broadcasts from Vatican Radio ${ }^{17}$, both of which - presumably with papal consent-disseminated views far more candid than the circumspect statements from the pope himself. The German government, predictably, took exception ${ }^{18}$. In an attempt to gather information about Eastern Europe, CNA had to draw upon sundry, but often suspect sources. For example, in the case of German- and Soviet occupied Poland, CNA recycled reports from a Polish newspaper ${ }^{19}$, the Polish embassy ${ }^{20}$, the Polish Information Center in New York ${ }^{21}$, and the Polish Catholic Press Agency ${ }^{22}$ - none of which could be characterized as a disinterested party. For the prewar areas of Russia CNA had to be content with materials from a white-Russian émigré newspaper Rossiia $^{23}$ and a German agency called Ost-Express ${ }^{24}$.

In 1943, faced with competition from other agencies (including one that claimed to have a correspondent in $\mathrm{Moscow}^{25}$ ), CNA sought Soviet permission to station a correspondent in Moscow. By then a Russian victory in the East seemed inevitable, and American Catholics - concerned about the postwar menace of Soviet communism - wanted reliable reports from within the USSR itself. CNA met with a representative of the Soviet embassy in Washington, but this initiative came to naught ${ }^{26}$. CNA also attempted to recruit the American Assumptionist priest serving in Moscow, Fr. Leopold Braun, to provide information. Although the priest's superior gave his assent, Braun himself - faced with growing Soviet pressure - refused, fearing that such activities would only make his position even more untenable ${ }^{27}$. Given the dearth of reliable news reports, CNA shifted its focus

16 Levack, A. P. (1974). Virgilio Scattolini, the Prince of Vatican Misinformers. Catholic Historical Review, 59, 719735.

17 For example, CNA, 5.IV.1943, p. 5.

18 Inside the Vatican of Pius XII; the Memoirs of an American Diplomat during World War II (2004). Tillmann, H., ed. New York, 40-41.

19 CNA, 1.V.1939, p. 10.

20 CNA, 2.X.1939, p. 25.

21 CNA, 21.VII.1941, p. 12

22 CNA, 16.XI.1942, p. 47.

${ }^{23}$ CNA, 29.VII.1940, p. 26 and 9.VI.1941, p. 15.

${ }^{24}$ CNA, 13.III.1939, p. 6. The full name was Der Ost-Express: Nachrichtendienst für Politik, Wissenschaft, Kultur; it operated out of Berlin between 1920 and 1943.

25 The Religious News Service, supported by a Jewish and Christian coalition, had been competing with CNA for several years, first trying to enlist CNA as a subscriber and later directly appealing to CNA's base of diocesan papers to collaborate and subscribe. Hall resisted the competition and appealed directly to 159 diocesan papers (CUA, Collection 10, Box 30, Folder 48, unpaginated (Frank Hall - editors, 9.VIII. 1944)).

${ }^{26}$ Citing a New York Times article based on an article from the Religious News Service about religious life in Russia (with claims to have a correspondent in Moscow), Hall arranged a meeting at the Soviet embassy in Washington, but his efforts were to no avail. CUA, Collection 10, Box 31, Folder 32, unpaginated (Hall to I. Anderson, 11.X.1944).

${ }^{27}$ An appeal to Braun through the U.S. embassy did not even reach its target; the letter was "returned from the State Department" (CUA, Collection 10, Box 31, Folder 32, unpaginated [Hall to Braun, 23.I.1943]. A year later Hall appealed to Braun's superior, the Rev. C. Armanet, emphasized the need for information about religious life 
from religious life to religious policy, especially in the territories occupied by Germany and the Soviet Union.

\section{From Isolationism to Intervention}

Throughout the 1930s CNA had contributed to the growing anti-communism among American Catholics ${ }^{28}$. This sentiment reflected the confrontation between the Vatican and Moscow from the late 1920s in response to the latter's antireligious campaign ${ }^{29}$. The repression of Catholic clergy and believers, along with the massive closing of churches, occupied a central place in CNA reporting and helped to fuel the growing anticommunism ${ }^{30}$. But it was not only a matter of repression in the USSR: communism posed an international threat, promoting atheist movements around the world ${ }^{31}$ and posing the threat of political subversion, even in the United States ${ }^{32}$. A leading exponent of the need to contain and combat Soviet communism was Edmund Walsh of Georgetown University, who had headed the Papal mission for famine relief in 1922-1923. He returned to America with an extremely negative view of the Soviet regime that he expressed in numerous publications and public lectures about the menace of Soviet communism ${ }^{33}$.

in Russia, adding that a competitor, Religious News Service, claimed that it will be receiving regular information directly from Russia (CUA, Collection 10, Box 31, Folder 22, unpaginated [Hall to Armanet, 21.VI.1944]). Armanet replied that he could not be of any assistance: "Father Braun has urged us to keep his name out of the newspapers, and never to allow any part of his letters to me to appear in print," since this "would increase the difficulty of his already delicate position". AT the most Armanet could only cull excepts from Braun's papers and any news that he sends (CUA, Collection 10, Box 31, Folder 22, unpaginated [Armanet - Hall, 22.VI.1944]). But Armanet later wrote to Hall that CNA should take this up with Braun, who can do as he sees fit [CUA, Collection 10, Box 31, Folder 22, unpaginated [Armanet to Hall, 29.VI.1944]). The most that CNA ever received, through Armanet, was a radiogram from Braun about a special mass held in honor of Franklin Roosevelt's fourth term (CUA, Collection 10, Box 31, Folder 22, unpaginated [radiogram, dated Moscow, 19 January 1945]). Hall was grateful, reiterating that "we have no news channels from Russia" (CUA, Collection 10, Box 31, Folder 22 unpaginated [Hall to Armanet, 2.II.1945]).

${ }^{28}$ For a substantive accounts, see: Frank, R. (1992). Prelude to the Cold War: American Catholics and Communism. Journal of Church and State, 34, 39-56; Gribble, R. (2008). Roman Catholicism and U. S. Foreign Policy, 19191935: A Clash of Policies. Journal of Church and State, 50, 73-99.

${ }^{29}$ Freeze, G. L. (2020). The American Catholic Press: Religious NEP, Repression, and Laicization (1925-1939). Новая и новейшая история, 64(6), 121-139.

${ }^{30}$ On the closing of Catholic churches, see the summary data in Zugger, C. L. (2001). The Forgotten: Catholics of the Soviet Empire from Lenin through Stalin. Syracuse, p. 237.

${ }^{31}$ Edwards, B. (2013). The Godless Congress of 1938: Christian Fears about Communism in Great Britain. Journal of Religious History, 37, 1-19.

32 In 1937 NCWC sponsored a project to study "communism in the United States," drawing upon data from 53 dioceses. Moreno, L. (1999). The National Catholic Welfare Conference and Catholic Americanism, 1919-1966. Ph.D. diss. University of Maryland, 63-64.

${ }^{33}$ In a typical speech Walsh portrayed "world control as the Soviet aim". CNA, 15.XI.1932, pp. 3-4. During the period 1924-1952 Walsh published four books and dozens of articles and delivered 2,000 lectures on the Soviet threat. McNamara, P. (2006). Russia, Rome, and Recognition: American Catholics and Anticommunsim in the 1920s. U.S. Catholic Historian, 24, 71-72. See also McNamara, P. (2005). Edmund A. Walsh, S. J., and the Politics of American Catholic Anticommunism. New York. 46-174. Walsh had played a key role in the Vatican aid program in the early 1920s and came away with an abiding distrust of the Soviet regime. See: Tokareva, E. S. (2021). The Adventures of a Jesuit in Russia: How the Soviet government fought with fr. Edmund Walsh (1922-1923). Electronic scientific and educational journal "History", 12, Issue 8 (106) [Electronic resource]. About Walsh and his role, see: Tokareva, E. S. (2020). Edmund Walsh, Vatican Plans and Russian Reality 1922-1923. Russian 
But the interwar period also brought the specter of a second adversary: fascism, first in Italy, then in Germany. The Vatican sought a modus vivendi with the regimes in both countries, concluding concordats with Italy (1929) and Germany (1933). The Vatican saw the concordats as a means to secure Church interests, but soon found that they provided scant protection of its rights and prerogatives. In March 1937 Pius XI castigated both fascism and communism in major encyclicals - the anti-fascist Mit Brennender Sorge and the anticommunist Divini Redemptoris ${ }^{34}$.

Despite the Vatican's even-handed repudiation of both forms of "totalitarianism" (a term increasingly popular at the time), the American Catholic press directed most of its attention toward Soviet communism. In the months preceding the outbreak of war in September 1939, CNA distributed multiple reports about Soviet anti-religious policy and especially its impact on Catholics. One dispatch, for example, described the near total decimation of Catholic clergy in the USSR (with 135 of 137 priests in prison or labor camps), thereby making it all but impossible for the faithful to observe even the high holy days ${ }^{35}$. As earlier, CNA seized upon the self-criticism of the League of Militant Atheists to show that lay piety persisted in unofficial, underground forms $^{36}$. CNA also drew attention to the continuing Soviet campaign to promote atheism abroad, including plans for a world congress of 2,500 godless ${ }^{37}$. The Molotov-Ribbentrop Nonaggression Pact of 23 August 1939 provided a golden opportunity to argue that Nazism and communism were bedfellows, and to pronounce the pact as an alliance of "the two greatest anti-Christian forces in the world" 38 .

Despite the fascist and communist threats, most American Catholics remained isolationist and strenuously opposed involvement in yet another European conflict. In a statement on "Peace and War" (November 1939), a conclave of American bishops openly opposed intervention in the war and pleaded "for a spirit of calm deliberation in our nation" 39 . Indeed, that

History, (4), 188-204; Dommarco, M. C. (2020). Un compito eccezionale e rischioso. II governo bolscevico e la missione della Santa Sede al tempo della carestia degli anni Venti. Mosca e Seriate.

${ }^{34}$ Wider den Rassismus (2001). Rauscher, A., ed. Paderborn; Passelecq, G. and Suchesky, B. (1997). The Hidden Encyclical of Pius XI. New York.

35 CNA, 13.III.1939, p. 6 (report from Geneva, 6.III.1939).

${ }^{36}$ A dispatch from Moscow in June 1939 cited the LMA publication Bezbozhnik, which admitted that underground convents had increased in recent years (CNA, 3.VII.1939, p. 4 [Moscow, 26.VI.1939]). Pravda reported that numerous anonymous letters with Biblical quotations were circulating and complained about LMA, declaring that "there is not the least enthusiasm here for the anti-religious fight." (CNA, 12.VI.1939, p. 52 [Moscow, 5.VI.1939]). One of the last reports from Moscow cited LMA publications, confirming that the catacomb church relied upon wandering priests and clandestine convents to sustain religious life (CNA, 18.III.1940, p. 18 [Moscow, 11.III.1940]).

37 CNA, 5.Vl.1939, p. 7 (Geneva, 29.V.1939).

${ }^{38}$ CNA, 28.VIII.1939, P. 61 (New York, 28.VIII.1939). The author, Fr. John LaFarge, was an American Jesuit active in the final years of Pius $\mathrm{XI}$, for whom he drafted a papal encyclical against racist and totalitarian ideologies, entitled Humani generis unitas. Pius XI, however, had not promulgated the encyclical before his death on February 10,1939 , and his successor, Pius XII, chose not to issue the document.

39 Huber, R. M. (1952). Our Bishops Speak. Milwaukee, 225-226; Pastoral Letters of the United States Catholic Bishops (1984). Nolan, H., ed. 4 vols. Washington. 1, 433-434. 
isolationism persisted despite the persecution of Catholic co-religionists in Poland by German and Soviet occupation forces ${ }^{40}$. A CNA staff writer cited the Soviet-German collaboration as proof that fascism and communism were only two forms of "totalitarianism" , and CNA pointed out a striking similarity in their anti-religious tactics: "In almost every respect Soviet persecution follows the example set by Hitler: the Church is not openly outlawed but the life of everyone who openly remains faithful to the Church is made a misery"42. Some, however, portrayed Moscow as the principal enemy. Edmund Walsh, for example, blamed "Russian communism for the present world strife"43, emphasized the need for "cool heads", and warned that a long war of attrition would give communists an opportunity to exploit ${ }^{44}$. Bishop Fulton Sheen, a popular figure in the media, blamed Moscow for causing the war and assailed the idea of "U.S.-Soviet friendship" 45 . A Soviet campaign vilifying the Vatican only intensified anti-Soviet sentiment ${ }^{46}$.

Roosevelt, increasingly inclined toward intervention, had to overcome resistance in the general public, but especially among Catholics. To ensure America's noninvolvement in foreign conflicts, the Neutrality Acts of 19351937 had imposed an embargo on the arms sales to belligerents. Roosevelt managed to make some inroads against the strict neutrality (notably, the "cash-and-carry" provision), but was rebuffed in his efforts to provide support for Britain and France. Only in March 1941 did the president succeed in persuading Congress to pass the Lend Lease Act allowing the United States to sell or give arms to Great Britain and France. After the German invasion of the Soviet Union on 22 June 1941 and the devastating Blitzkrieg that ensued, Roosevelt lobbied to extend Lend Lease to the USSR, but encountered strong resistance from American Catholics ${ }^{47}$. To overcome opposition among American Catholics, Roosevelt turned to the Vatican for assistance and, in

${ }^{40}$ On the impact of the Soviet occupation of Poland and the "winter war" with Finland, see: Moreno, L. (1999). The National Catholic Welfare Conference and Catholic Americanism, 1919-1966. Ph.D. diss. University of Maryland, $75,79-80$.

${ }^{41}$ Immediately after the German invasion of the Soviet Union, a staff writer for CNA, Elmer Murphy, showed no sympathy for the Soviets. He condemned both Nazism and communism as anti-democratic and concluded that there was little difference between the two. CNA, 30.VI.1941 (Washington, 30.VI.1941).

42 CNA, 3.VI.1940, P. 5 (London, 27.V.1940).

43 CNA, 18.XII.1940, P. 49 (Washington, 18.XI.1940).

${ }^{44}$ Dr. Walsh Stresses Need of 'Cool Heads' to Preserve Peace in America (CNA, 9.IX.1939, p. 58 [New York, 9.X.1939]).

45 CNA, 9.XII.1940. P. 55 (New York, 8.XII.1940). Sheen was a prominent radio (and later television) personality. See: Farney, K. D. (2016). Golden Mouths, Ethereal Pulpits: The Remarkable Radio Success of Reverend Walter A. Maier, Ph.D. and Monsignor Fulton J. Sheen, Ph.D. Ph.D. diss., University of Notre Dame, 57-147; Epple, M. (2001). American Crusader: Bishop Fulton J. Sheen's Campaign against Germany. Ph.D. diss. University of Akron, P. 42-100.

46 In response to the death of Pius XI, the Soviet press - as CNA reported - had denounced the pope as an archenemy of communism and a "defender of capitalism." CNA, 6.III.1939, P. 9 (Moscow, 28.II.1939); 14.II.1939, P. 13 (Moscow, 12.II.1939).

47 Cardinal Francis Spellman of New York wrote to Pius XII to warn him of the intense debate about aid to the Soviets, with the vast majority of Catholic prelates firmly opposed. See Actes es documents du Saint-Siège relatifs à la seconde guerre mondiale [hereafter ADDS]. (1969). Ed. Blet, P., Graham, R., Martini, A., Schneider, B. 12 vols. Vatican City, 1965-1981. 5, 181-182. 
a letter of 3 September 1941, assured Pius XII that "Russia may as a result of the present conflict recognize freedom of religion" ${ }^{48}$. In October Roosevelt created a public furor when he cited article 124 in the Stalin constitution of 1937, guaranteeing religious freedom, as though it described actual conditions ${ }^{49}$. The president, through his personal representative, urged the pope to persuade American bishops to support Lend Lease for the Soviet Union ${ }^{50}$. Pius XII did so, through private communications to the Apostolic Delegate in Washington, but with strict orders to keep his intercession confidential ${ }^{51}$. The Catholic bishops acceded, but without enthusiasm. That was evident in their collective statement, "Crisis in Christianity," which reaffirmed opposition not only to fascism but also to communism ${ }^{52}$. Archbishop Michael Curley of Washington was unrestrained, calling Stalin "the greatest murderer of men the world has ever known" 53 . Walsh supported the expansion of Lend Lease but insisted on "plain talk" to avoid deluding Americans about the true nature of the Stalin regime ${ }^{54}$.

The Japanese attack on Pearl Harbor (7 December 1941) put an end to isolationist sentiment among American Catholics. The chair of NCWC, Archbishop Edward Mooney of Detroit, wrote to Roosevelt that "we will do our part" 55 . American bishops signed a joint declaration vowing to support the war effort and earned an immediate letter of gratitude from the president. It was not a matter of mere words: Catholics comprised 31 percent of the army and even higher proportions in the air force and navy. Several thousand priests served as chaplains; some perished at the front and a number earned medals for their valor and self-sacrifice ${ }^{56}$.

\section{From Reticent to Vociferous Anticommunism}

Support for the war initially led CNA to avoid hostile rhetoric about the Soviet ally. Yet that reticence stood in marked contrast to the pro-Soviet exuberance of the time, a mood reflected in an American journalist's account, We're in This

${ }^{48} A D D S, 5,180$. The Vatican had a very different picture of conditions in Russia. In a note to Roosevelt's personal emissary, Domenico Tardini (a key papal aide) provided a devastating picture of religious repression in the Soviet Union (ADDS, 5, 241-244). The Vatican asked the State Department for evidence of greater religious tolerance, but the latter candidly admitting that it had none. Inside the Vatican of Pius XII; the Memoirs of an American Diplomat during World War II (2004). Tillmann, H., ed. New York, 58.

49 For the speech and fierce criticism, see CNA, 6.X.1941, P. 1-3 (Washington, 3.X.1941). See the trenchant critique by the normally tactful Walsh: CNA, 6.X.1941, P. 3-5 (Washington, 2.X.1941).

50 According to Amleto Cicognani (Apostolic Delegate to the United States), by September 1941 a majority of American bishops supported aid for the Soviet Union, but still opposed intervention. Blet, P. (1997). Pius XII and the Second World War. According to the Archives of the Vatican. New York: Paulist Press, 110-121. See also ADDS, Vol. 5, P. 199-200, 240-441.

51 Graham, R. (1996). The Vatican and Communism during World War. San Francisco. 34-40 (with a reference to the confidential instructions to American bishops, p. 38).

52 Pastoral Letters of the United States Catholic Bishops (1984). Nolan, H., ed. 4 vols. Washington. 2, 28-35.

53 Sirgiovanni, G. (1990). An Undercurrent of Suspicion: Anti-Communism and Anti-Soviet Opinion in World War II America. New Brunswick, 53.

54 CNA, 3.XI.1941, P. 28 (New York, 31.X.1941).

55 Pastoral Letters of the United States Catholic Bishops (1984). Nolan, H., ed. 4 vols. Washington. 2, 36-37.

56 Pastoral Letters of the United States Catholic Bishops (1984). Nolan, H., ed. 4 vols. Washington. 2, 13. 
with Russia ${ }^{57}$. But Catholics remained distrustful and understandably so, given the flood of new details about Soviet religious repression in the occupied territories of Poland ${ }^{58}$, Baltics, Belorussia, and Ukraine). Reports on Russia, though rare, confirmed that the regime continued to persecute Catholics; a dispatch from Canada, for example, reported that 110 to 150 priests from the Catholic dioceses of Mogilev and Saratov were currently in prison or labor camps ${ }^{59}-$ rough estimates that reflect the poor quality of available information. American bishops thus continued to equate Nazism and communism; a declaration of 16 November 1942, signed by 102 bishops, repudiated both Nazi and communist "totalitarianism"60. This antipathy toward the Soviet Union was not unique: one opinion poll showed that 45 percent of the general population deemed the Soviet ally to be immoral, and 30-40 percent declared it untrustworthy ${ }^{61}$.

Open criticism of the Soviet regime, ironically, resumed after the appearance of a Soviet propaganda volume, purportedly from the Russian Orthodox Church, called The Truth about Religion in Russia ${ }^{62}$. In 1942 the regime had arranged the preparation and publication of the Russian text (which was then translated into English), the goal being to counteract the opposition of Western believers to providing aid to the Soviet Union because of its record of persecuting religion ${ }^{63}$. The English translation began to attract attention in early 1943 and by March the Catholic media were actively engaged in rebutting this apologia. CNA first published a Swiss newspaper critique and later carried a stream of highly critical commentaries. One article identified falsehoods and the patently propagandistic purpose, noting that it had been published almost entirely for distribution in Great Britain and the United States ${ }^{64}$. Despite the Vatican's policy of neutrality, the papal yearbook for 1943 (Annuario pontificio per l'anno 1943) pointed out that all six Catholic ecclesiastical jurisdictions in the USSR were still without a bishop $^{65}$.

The renewed attacks on the Soviet regime were no doubt due to a shift in the fortunes of war: after the Battle of Stalingrad, Moscow seemed increasingly

57 Carroll, W. (1942). We're in This with Russia. Boston: Houghton Mifflin.

58 In March 1941, for example, Catholics in London published a report by the ranking prelate in Poland: Hlond, A. (1941). The Persecution of the Catholic Church in German Occupied Territories. New York.

${ }^{59}$ CNA, 23.11.1942 (Quebec, 20.XI.1942).

60 CNA, 16.XI.1942, P. 31-45; Pastoral Letters of the United States Catholic Bishops (1984). Nolan, H., ed. 4 vols. Washington. 2; Hlond, A. (1941). The Persecution of the Catholic Church in German Occupied Territories. New York. 38-45.

61 McNamara, P. (2005). Edmund A. Walsh, S. J., and the Politics of American Catholic Anticommunism. New York, 107-108.

62 Правда о религии в России (1942). Под ред. Николая (Ярушевича). М. The English translation, bearing the title The Truth about Religion in Russia, Issued by the Moscow Patriarchate, was published in London, 1942 (with multiple reprintings in subsequent years). A German edition, Die Wahrheit über die Religion in Rußland, was published in Zurich, 1944. For an overview, see Sirgiovanni, G. (1990). An Undercurrent of Suspicion: AntiCommunism and Anti-Soviet Opinion in World War Il America. New Brunswick, 252-253.

63 For a concise summary see: Фирсов, С. Сталинский конкордат. Независимая газета, 3 сент. 2003. Available: https://www.ng.ru/ng_religii/2003-09-03/6_konkordat.html (accessed: 10 July 2021).

${ }^{64}$ CNA, 1.III.1943, P. 1-9 (Lisbon, 22.II.1943). The lengthy article bore the title: "Soviet Volume Misrepresents Religious Situation in Russia."

65 CNA, 3.V.1943, P. 1 (Washington, 30.IV.1943) 
certain to defeat the Nazis. CNA's mother organization, NCWC, continued to disseminate attacks on the Nazis ${ }^{66}$, but CNA's focus - with the rising probability of a Soviet victory - shifted toward the menace of communism. While Soviet victories on the battlefield promised a favorable outcome to the war, Catholics saw a growing fear of Soviet domination. CNA took its cue from the Holy See, such as a broadcast from Vatican Radio in April 1943 repudiating reports that the pope had directed the archbishop of Westminster to invoke prayers for Bolshevism. The dispatch emphasized that Pius XI in Divini Redemptoris and Pius XII in his Christmas eve message of 1942 had expressed a love for the Russian people but explicitly repudiated "atheistic communism". Hence the archbishop's remarks had been misconstrued, for he had referred only to the Russian people, not Bolshevism ${ }^{67}$. In June 1943 CNA published a blistering critique of a new American feature film, Mission to Moscow, based on the memoir of the American ambassador, Joseph Davies ${ }^{68}$. Given its sympathetic portrayal of the Stalin regime, a staff writer at CNA called it nothing other than a "propaganda film" and asked why it was ever made ${ }^{69}$. That same month CNA reported about a broadcast from Vatican Radio describing the Vatican's frustration over the Soviet refusal to provide information about prisoners of war - one of the pope's key "neutral" initiatives to mitigate the hardships on both sides ${ }^{70}$.

Stalin's apparent volte-face in religious policy in 1943 did not impress American Catholics, given the steady flow of CNA reports about religious persecution. A CNA dispatch of April 1943, for example, summarized a talk by the senior correspondent of Time-Life in Russia, who described the multifarious methods used to repress religious life - exorbitant taxes, discrimination against churchgoers, and inability to train new ordinands. Even without direct repression, these measures served to cause a significant decline in churches, not only Catholic, but also Orthodox ${ }^{71}$.

When Stalin famously authorized the reestablishment of the patriarchate and made other concessions to the Orthodox Church in September 1943, the news feeds from CNA remained highly skeptical. The agency noted, for example, that the British Catholic press was "cautious" about the purported shift in policy. The Catholic Herald (London) dismissed the shift as a maneuver "to counteract hostility from Christian quarters, especially in the United States," and warned

${ }^{66}$ For example, in 1943 NCWC published a volume detailing the Nazi persecution in Europe along with some other key anti-Nazi documents: National Catholic Welfare Council (1943). The Nazi War against the Catholic Church. Washington, DC.

${ }^{67}$ CNA, 5.IV.1943, p. 5 (Vatican City, 30.III.1943). The broadcast spoke on behalf of Hinsley, who had died shortly earlier (17.III.1943).

68 Sirgiovanni, G. (1990). An Undercurrent of Suspicion: Anti-Communism and Anti-Soviet Opinion in World War II America. New Brunswick, 256-257.

69 The headline ran: "Mission to Moscow film Receives Deluge of Adverse Criticism". CNA, 7.VI.1943, P. 33-34 (Washington, 7.VI.1943).

70 CNA, 14.VI.1943, P. 21 (London, 7.VI.1943). Earlier CNA wrote that the Soviet side had "something to hide" and offered a dark reference to Katyn. CNA, 3.V.1943, P. 33-34 (Washington, 3.V.1943). On the Vatican's initiative to assemble information about prisoners of war, see: Alvarez, D. and Graham R. (1997). Nothing Sacred: Nazi Espionage against the Vatican, 1939-1945. London: Frank Cass. 140.

71 CNA, 19.IV.1943, P. 40-41 (New York, 20.IV.1943). 
that a revived Orthodox Church may renew "its traditional hostility to Rome" and thus undermine "Catholic missions to convert Russia"72. A staff writer for CNA pointed out that the Stalin's apparent shift did not apply to the Catholic Church and reported that politicians in Washington looked askance at the sincerity of the new religious tolerance ${ }^{73}$. Secular papers likewise took a cautious, "wait-and-see" view ${ }^{74}$. When Moscow established a new council on the religious affairs of non-Orthodox confessions, the CNA published dispatches expressing continuing doubts about the purported liberalization in policy ${ }^{75}$.

By early 1944, the Cold War between the Soviet Union and Catholicism was in full gear. A major confrontation occurred in February 1944, when Catholic papers declared that the Soviet regime had launched a full-scale campaign against the Vatican "as a menace to future peace". Indeed, Soviet media cited a publication from the Foreign Policy Association in the United States, which - it asserted - supported the view that Pius XII was sympathetic to the fascist cause ${ }^{76}$. CNA distributed the response of British Catholic papers, such as the Universe, which denounced Izvestiia ${ }^{77}$ for seeking to "drag up the history of the past few years" and added a sarcastic remark that, given recent Soviet history, "nobody has more reason to wish for oblivion of this period" "78. The diocesan paper in Portland Oregon characterized the Soviet regime as "a completely totalitarian government"79. Bishop Fulton Sheen invoked the authority of the Vatican, citing the papal pronouncements against all forms of totalitarian government, communist as well as fascist ${ }^{80}$. No less acerbic was the Witness (the diocesan newspaper in Dubuque, Iowa): "Communism is the death and destruction of peace, justice, freedom, civilization for which we are fighting" ${ }^{81}$. CNA also recycled critical comments in the leading secular papers, such as the New York Times and the Washington Post ${ }^{82}$.

72 CNA, 13.IX.1943, P. 41 (London, 21.IX.1943).

${ }^{73}$ CNA, 27.IX.1943, P. 32-33 (Washington, 27.IX.1943).

${ }^{74}$ CNA, 27.IX.1943, P. 37.

75 CNA, 3.VII.1944, P. 50.

76 The publication (Hayden, Sh. (1944). Foreign Policy of the Vatican. Foreign Policy Reports, 19(21), $277-$ 288), in fact affirmed that neither Pius XI nor Pius XII favored fascism or wanted to see the triumph of "modern dictatorships." Nevertheless, Hayden did qualify this statement, declaring that Pius XII "is not a supporter of democracy but just what he claims to be-indifferent to political forms." See also the report in CNA, 14.I.1944, P. 42 (Washington, 17.I.1944).

77 The Izvestiia article portrayed the Vatican as fascist. See Powers, R. G. (1995). Not without Honor; the History of American Anticommunism. New York: Free Press, 174.

78 CNA, 7.II.1944, P. 53 (London, 7.II.1944). Another dispatch in CNA castigate the Izvestiia article as nothing but a "lie". CNA, 7.II.1944, P. 3-04 (n.p., n.d.). Secular papers in the United States joined in this denunciation of the Soviet anti-Vatican claim; see CNA, 8.II.1944, P. 6 (Philadelphia, 8.II.1944). Almost simultaneously a newly published book also came to the pope's defense: Sharkey, D. (1944). White Smoke over the Vatican. Milwaukee: Bruce Publishing Co. See also the report in CNA, 21.II.1944, P. 23 (18.II.1944, Milwaukee).

${ }^{79}$ CNA, 7.II.1944, P. 6 (n.p., n.d.).

${ }^{80}$ CNA, 8.II.1944, P. 9-10 (Washington, 8.II.1944). Sheen did not mince words: "No country in the world has contributed as much to Fascism as Russia," and cited the 1939 Molotov-Ribbentrop Pact. Sheen added that "fascism is really communism in its dotage. Communism is the Asiatic form of fascism, and fascism is the European form of communism." CNA, 2.II.1944, P. 1-3 (Washington, 2.II.1944).

81 CNA, 7.II.1944, P. 55-56 (n.p., n.d.).

${ }^{82}$ CNA, 7.II.1944, P. 4, 34. (n.p., n.d.). 
The visit of an American priest in April 1944, organized by Moscow as a propaganda stunt, did not quell the criticism but ignited a storm of protests ${ }^{83}$. The priest, Stanislaus Orlemanski, journeyed to Moscow at Stalin's invitation and met with him twice to discuss the religious situation in Poland ${ }^{84}$. Fr. Orlemanski evidently made the trip with the approval of the White House and U.S. State Department, which were loath to spurn a request from the Kremlin ${ }^{85}$. Once news broke about Orlemanski's visit and his apparent endorsement of Soviet policy, the result was an explosion of furious denunciations in the Catholic press. The priest (who evidently hoped to extract concessions for co-religionists in Poland) was suspended from parish service and consigned to a monastery for an indefinite period $^{86}$. Although Orlemanski soon apologized ${ }^{87}$, the episode deepened Catholic suspicions and distrust of the Kremlin machinations and its attempt to manipulate naïve Western opinion ${ }^{88}$.

CNA continued to report shocking evidence of antireligious repression in the newly occupied territories. One CNA dispatch, for example, cited "reliable reports from Lithuania" that the Soviets were continuing to subject Catholic clergy to repression, even execution ${ }^{89}$. The only functioning Catholic church in Moscow, manned by an American Assumptionist priest, was formally tolerated because of an earlier agreement with Roosevelt, but the priest served tens of thousands of Soviet Catholics denied access Catholic churches in their own area $^{90}$. CNA also reported the multiple robberies at the church, which was literally

83 The visit of an Anglican prelate in October 1943 had elicited similar criticism. CNA, 11.X.1943, P. 13 (dispatch by George Barnard, the London correspondent of NCWC, dated 5.X.1943). Key documents on the Orlemanski visit include: Father Stanislaus Orlemanski at News Conference (https://www.gettyimages.com/detail/video/fatherstanislaus-orlemanski-at-news-conference-exterior-news-footage/504408159); Запись беседы И. В. Сталина с ксендзом Ст. Орлеманским (1997). Восточная Европа в документах российских архивов, 1944-1953 гг. Редкол.: Г. П. Мурашко (отв. ред.) и др. Новосибирск. 36-42; Record of a Conversation between I. V. Stalin and the Roman Catholic Priest Stanislaus Orlemanski (https://digitalarchive.wilsoncenter.org/document/123130).

${ }^{84}$ On the Orlemanski affair, see: Moreno, L. (1999). The National Catholic Welfare Conference and Catholic Americanism, 1919-1966. Ph.D. diss. University of Maryland, 108-109; Sirgiovanni, G. (1990). An Undercurrent of Suspicion: Anti-Communism and Anti-Soviet Opinion in World War II America. New Brunswick, 268-274; Stehle, H. (1981). Eastern Politics of the Vatican 1917-1979. Athens, Ohio. 320-321.

85 См.: Токарева, Е. С. (2019). Ватикан в фокусе советской политики (1938-1988). Россия в мире. М., Весь мир. 405-437.

${ }^{86}$ CNA, 15.V.1944, P. 44 (Springfield, 15.V.1944).

87 CNA, 16.V.1944, P. 7 (Springfield, 16.V.1944).

${ }^{88}$ For the protest by a delegation of "six million Polish-Americans" along with the claim that Orlemanski was a communist sympathizer, see CNA, 8.V.1944, P. 33, 43. The American Catholic press published numerous complaints that Fr. Orlemanski had been "used as a tool of policy-makers in the Kremlin" (CNA, 15.V.1944, P. 41-42 [Washington, 13.V.1944]). For Orlemanski's apology and restoration to his parish, see CNA, 16.V.1944, P. 7 (Springfield, MA, 16.V.1944)

${ }^{89}$ CNA, 13.XI.1944, P. 5 (Zurich, 10.XI.1944).

90 The Moscow parish of Fr. L. Braun, according to a report from April 1943, serviced 25,000-30,000 of the faithful. CNA, 19.IV.1943, P. 40-41 (19.IV.1943). The Assumptionist archive in Boston, significantly, holds a large number of baptism, marriage, and confirmation certificates for the years of 1942-1949. Assumptionist Center, Russian files (uncatalogued). In early 1945 CNA still carried reports about the flood of provincial Catholics coming to Braun's parish. CNA, 5.Il.1945, P. 4 (n.p., n.d.). See also: Жданова, E. C. (2021). Установление контроля советской власти над католическим храмом св. Людовика в Москве в 1947-1950 гг. (по документам Совета по делам религиозных культов при Совете Министров СССР). Электронный научно-образовательный журнал “История”, 12, 8(106) [Available: https://history.jes.su/issue.2021.3.8.8-106/ (restricted access).]. 
in the shadows of Lubianka, making Soviet claims of ordinary criminal activity incredible.

As the victorious allies began laying postwar plans, the Catholic press became increasingly concerned about Soviet annexation of territories to the West, especially Catholic Poland and Lithuania ${ }^{91}$. In November 1943 NCWC adopted a statement on "Essentials of a Good Peace", which expressed fears that the American government might "compromise on the ideals of the Atlantic Charter", especially the mandate for religious freedom ${ }^{92}$. In March 1944 CNA reported the earlier mass deportation of 1.2 million Poles ${ }^{93}$ and the continuing religious persecution in Lithuania ${ }^{94}$. Such complaints drew support from the Vatican newspaper L'Osservatore Romano, which published a recent address by Pius XII to Polish soldiers ${ }^{95}$ and raised the question of Polish territorial boundaries ${ }^{96}$. In November 1944 American bishops adopted an extremely caustic denunciation of the Soviet government (characterized as a regime of "cruel inhuman aggressors") and demanded unqualified defense of Poland: "American Catholics would ever resent this country's being made a party for the de-Christianization of historic Catholic peoples"97. The Vatican newspaper later took exception to statements by British leaders (Winston Churchill and Antony Eden) and warned that any territorial settlement could profoundly affect Europe's future ${ }^{98}$. CNA offered its own warnings about "the insatiable demands of Soviet Russia" and the need to defend Poland ${ }^{99}$. Suspicion that Western leaders were preparing to betray Polish - and Catholic - interests found incontrovertible evidence in the Yalta agreement $^{100}$. The Polish diaspora in America was especially vociferous in denouncing Yalta "as a betrayal of Poles"101. Yalta was indeed a central target of Catholic outrage and denounced as "a surrender to Russia" that turned nine million Polish Catholics over to the Soviet Union ${ }^{102}$. The Jesuit Sovietologist, Walsh, delivered a speech berating the Soviet triumph at Yalta and decrying its decision on Poland as "a highly dangerous precedent" 103 .

A further important dynamic was the open confrontation between the Vatican and Moscow. In May 1944 Pravda distributed a declaration from the Russian

91 The CNA staff writer, Elmer Murphy, made multiple postings about the growing concern over Soviet ambitions after the war: CNA, 15.III.1943, P. 54 (Washington, 15.III.1943); 30.VIII.1943, P. 39 (Washington, 30.VIII.1943); 15.X.1943, P. 32 (Washington, 15.X.1943).

92 Pastoral Letters of the United States Catholic Bishops (1984). Nolan, H., ed. 4 vols. Washington. 2, 44-49.

${ }^{93}$ CNA, 15.V.1944, P. 36.

94 CNA, 13.III.1944, P. 6.

95 CNA, 14.VIII.1944, P. 40.

${ }^{96}$ CNA, 4.XII.1944, P. 4-5 (Vatican City, 1.XII.1944).

97 Huber, R. M. (1952). Our Bishops Speak. Milwaukee, 234-235; Pastoral Letters of the United States Catholic Bishops (1984). Nolan, H., ed. 4 vols. Washington. 2, 52.

98 CNA, 1.I.1945, P. 32 (Vatican City, 29.XII.1944).

99 CNA, 15.I.1945, P. 16 (London, 8.I.1945).

${ }^{100}$ CNA, 5.III.1945, P. 1-2 (Glasgow, 2.III.1945)

${ }^{101}$ CNA, 19.II.1945, P. 5 (Washington, 16.II.1945). For another denunciation by a Polish exile leader, see CNA, 13.Il.1945, P. 1 (n.p., n.d.).

${ }^{102}$ CNA, 13.II.1945, P. 1 (n.p., n.d.) See also the discussion and references in Sirgiovanni, G. (1990). An Undercurrent of Suspicion: Anti-Communism and Anti-Soviet Opinion in World War Il America. New Brunswick, 261-263.

${ }^{103}$ CNA, 12.III.1945, P. 61 (Boston, 11.III.1945). 
Orthodox Church attacking the pope's claim to be the "vicar" of Christ ${ }^{104}$. The apparent willingness of the Orthodox Church leaders to serve the communist state led to a dispatch describing it "as a tool of policy-makers in the Kremlin" 105. The chair of the NCWC issued a similar denunciation ${ }^{106}$. Rumors in the summer of 1944 - reportedly emanating from Moscow - claimed that the Vatican and Soviets were actively coordinating plans for the postwar era. In response, L'Osservatore Romano indignantly repudiated such reports as totally unfounded ${ }^{107}$.

The acrimony became especially intense after the Soviet press launched a fullscale attack on the Holy See in early 1945. In response to the pope's attempt (in the Christmas address of 1944) to ensure a just peace and avoid the vindictive reparations of Versailles, the Soviet press portrayed his speech as tantamount to giving refuge to Nazi war criminals. CNA distributed a rebuttal by L'Osservatore Romano, which accused the Soviet press of grossly distorting the pope's words ${ }^{108}$ and raised anew the issue of Soviet war guilt - for causing for the outbreak of the war through the Molotov-Ribbentrop pact ${ }^{109}$. The Orthodox Church, presumably at the Kremlin's instigation, reiterated such accusations, much to the fury of Catholics in the West ${ }^{110}$. In April Ilya Ehrenburg published a piece in Pravda, asserting that the pope was seeking to "whitewash the [Nazi] criminals" 111 . The famous writer provoked a torrent of fierce criticism and a warning that American cooperation in making a peaceful postwar Europe was being "made difficult by Soviet propaganda attacks" $" 112$. NCWC did not spare its own rhetoric: in March it published a pamphlet with the title Communism Today, or Red Fascism ${ }^{113}$. In short, by 1945 American Catholics had emerged as the leading anti-communist force a role that it would continue to play in the first decade of the Cold War ${ }^{114}$.

\section{The Pius War: Neutrality and News}

After his death in 1958, the pope's wartime reticence - his refusal to name specific countries guilty of war crimes - became the focus of acrimonious historiographic debates, aptly described as the "Pius War" 115 . That criticism,

\footnotetext{
${ }^{104}$ CNA, 16.V.1944, P. 1 (London, 16.V.1944), citing an Orthodox Church article in Zhurnal moskovskoi patriarkhii by the late patriarch Sergii.

${ }^{105}$ CNA, 15.V.1944, P. 38 (London, 13.V.1944).

${ }^{106}$ CNA, 8.V.1944, P. 1 (London, 5.V.1944).

${ }^{107}$ CNA, 14.VIII.1944, P. 40 (Vatican City, 14.VIII.1944).

${ }^{108}$ CNA, 30.I.1945, P. 5 (Vatican City, 30.I.1945).

${ }^{109}$ CNA, 19.II.1945, P. 38 (Vatican City, 17.II.1945). See also: CNA, 19.Il.1945, P. 45 (Vatican City, 19.II.1945).

${ }^{110}$ CNA, 26.II.1945, P. 22 (Msg. Edward Hawks, special contribution to NCWS)

111 Эренбург, И. (1945). Сказка про белого бычка. Правда, 25.III.1945.

${ }^{112}$ CNA, 2.IV.1945, P. 26 (Washington, 2.IV.1945).

${ }^{113}$ Feely, R. (1945). Communism Today, or Red Fascism. New York.

${ }^{114}$ Chamedes, G. (2019). A Twentieth-Century Crusade: The Vatican's Battle to Remake Christian Europe. Cambridge MA.

${ }^{115}$ The literature on the "Pius War" is enormous. For a balanced overview see: Sanchez, J. (2002). Pius XII and the Holocaust: Understanding the Controversy. Washington, DC; Doino, W. Jr. (2004). An Annotated Bibliography of Works on Pius XII, the Second World War and the Holocaust. The Pius War: Responses to the Critics of Pius XII. Ed. Bottum, J. and Dalin, D. Lanham, 97-280; Kösters, Ch. (2018). Catholics in the Third Reich: An Introduction to the Scholarship and Research History. Catholics and the Third Reich. Boston. 37-60; Johnson, W. (2020). Blood Libel and the Pius War. Journal of Religious and Theological Information, 19, 57-69.
} 
however, was not new; it arose during the war among the Allies, who sought a forceful papal denunciation of the Axis powers that would serve to mobilize public opinion. The pope's defenders argue that Pius XII did denounce atrocities (as in his Christmas eve message of 1942), with the identity of the perpetrators obvious to all, but left unnamed for a host of legitimate reasons: fear that such denunciations would only provoke vicious Nazi retribution, that they would subject the Vatican itself to direct assault, that they would alienate the patriotic German and Italian Catholics, that they should also include the crimes committed by the Allies (whether by Soviet occupation forces or by Allied aerial attacks on civilian populations), that they would violate the political neutrality mandate of the 1929 Lateran Concordat, and that they would compromise the pope's impartiality and eliminate any hope of mediating the conflict. Hence Pius XII offered only general statements about atrocities and avoided declarations that might be construed as pro-Ally or pro-Axis.

Still, even if personally silent, the pope did speak indirectly through Catholic media $^{116}$. He tolerated acerbic rhetoric in the semi-official Vatican newspaper L'Osservatore Romano and in broadcasts from Vatican Radio, provoking criticism from both sides of the conflict ${ }^{117}$. Catholic media outside the Vatican were far more vociferous. Contrary to the myth of all-encompassing Vatican control, Pius not only tolerated but encouraged independent journalism. This corresponded to his strategy of "glocalizing" power and empowering bishops to use their own best judgement - partly to avoid compromising Vatican neutrality, partly to recognize that local authorities knew best what was possible and effective ${ }^{118}$. In the case of CNA, the Vatican facilitated the rising crescendo of anticommunism, not least by providing a major source of news. It was therefore no accident that the Holy See turned a blind eye to the escalation of anticommunist, anti-Soviet rhetoric in the last two years of the war. It is not as though the Vatican remained ignorant of the American Catholic press and its strident anticommunism: the NCWC regularly reported on its meetings and decisions to the Vatican ${ }^{119}$. In effect, CNA and the American diocesan press were able to articulate views that the pope himself, given his commitment to neutrality, could not. This was precisely the same strategy that Pius XII exercised with respect to the German hierarchs ${ }^{120}$. The enormous literature about the alleged "silence" of Pius XII, significantly,

${ }^{116}$ The popular view that the papacy had total control over Catholics around the world was indeed widespread. But that has long since been contested; see, for example, Sanchez, J. (2002). Pius XII and the Holocaust: Understanding the Controversy. Washington, DC. 137.

117 On Allied criticism of the papacy's silence, see Inside the Vatican of Pius XII; the Memoirs of an American Diplomat during World War II (2004). Tillmann, H., ed. New York, 115-116.

${ }^{118}$ Repgen, K. (1995). Die deutschen Bischöfe und der zweite Weltkrieg. Annuario de historia de la Iglesia, 4 , 131. The "localization" strategy was explicit in a letter from Pius XII to Bishop Konrad Preysing of 30 April 1943 , published in: Die Briefe Pius XII an die deutschen Bischöfe 1939-1944. (1966). Schneider, B., Blet, P., and Martini, A., Eds. Mainz. 240.

${ }^{119}$ Boyea, E. (1987). The National Catholic Welfare Conference: An Experience in Episcopal Leadership, 1935-1945. Ph.D. diss. Catholic University of America. 222-230.

${ }^{120}$ See the correspondence from Pius XII in: Die Briefe Pius XII an die deutschen Bischöfe 1939-1944. (1966). Schneider, B., Blet, P., and Martini, A., Eds. Mainz. A close analysis of the interaction between Pius XII and a German prelate is to be found in: Wolf, H. (2009). Papst Pius XII. und die Juden. Theologische Revue, 105(4), 265-280. For an excellent case study, see: Brodie, Th. (2018). German Catholicism at War, 1939-1945. Oxford. 
has failed to recognize how the pope used surrogates like CNA to address the travesties and atrocities of the war ${ }^{121}$. By tacitly permitting the Catholic press (like the German prelates) to act independently, the Vatican enabled the pope to maintain his "neutrality" even while permitting the Catholic media and national clergy to articulate what he could not. To be sure, this is contrary to the "centralized" stereotype widely shared by contemporaries and still prevalent in the historiography. But precisely for this reason it was the perfect solution to the papal quandary. In effect, the papacy practiced what is now a commonplace in globalization studies: to survive and thrive, adapt to the local conditions - what is commonly called "glocalization." In the case of Pius XII, it enabled him to maintain the myth of supranational neutrality, yet unleash Catholics at the local level to act as circumstances permitted.

Relationship and Activities. This article is part of a project supported by the Russian Science Foundation (No. 19-18-00482), "Entangled Histories: Russia and the Holy See, 1917-1958".

\section{Литература}

1. Васильева, О. Ю. (2001). Русская православная церковь и политика советского государства в 1943-1948 гг. М.

2. Русская православная церковь в годы Великой отечественной войны 1941-1945 гг. (2009). Васильева, О. Ю., Кудрявцев, И. И., Лыкова, Л. А., ред. Сборник документов. М.

3. Запись беседы И. В. Сталина с ксендзом Ст. Орлеманским (1997). Восточная Европа в документах российских архивов, 1944-1953 гг. Редкол.: Г. П. Мурашко (отв. ред.) и др. Новосибирск. 36-42.

4. Одинцов, М. И. (2005). Власть и религия в годы войны. М.

5. Токарева, Е. С. (2020). Эдмунд Уолш, планы Ватикана и российская действительность 1922-1923 гг. Российская история, (4), 188-204

6. Токарева, Е. С. (2021). Приключения иезуита в России: Как советская власть боролась с о. Эдмундом Уолшем (19221923 гг.). Электронный научно-образовательный журнал “История”, 12, Выпуск 8 (106) [Электронный ресурс]

7. Фирсов, С. Сталинский конкордат. Независимая газета, 3 сентября 2003. Available: https://www.ng.ru/ng_religii/ 2003-09-03/6_konkordat.html. (accessed: 10 July 2021).

8. Шкаровский, М. В. (1999). Русская православная церковь при Сталине и Хрущеве. М.

9. Эренбург, И. (1945). Сказка про белого бычка. Правда, 25.III.1945.

10. Actes es documents du Saint-Siège relatifs à la seconde guerre mondiale [hereafter ADDS]. (1969). Ed. Blet, P., Graham, R., Martini, A., Schneider, B. 12 vols. Vatican City, 1965-1981. 5.

11. Alvarez, D. (2002). Spies in the Vatican. Espionage \& Intrigue from Napoleon to Holocaust. Lawrence, Kansas.

12. Alvarez, D. and Graham R. (1997). Nothing Sacred: Nazi Espionage against the Vatican, 1939-1945. London: Frank Cass.

13. Barone, M. (2003). Franklin D. Roosevelt: A Protestant Patrician in a Catholic Party. FDR, the Vatican, and the Roman Catholic Church in America, 1933-1945. ed. David Woolner and Richard Kurial. New York. 3-10.

14. Blet, P. (1997). Pius XII and the Second World War. According to the Archives of the Vatican. New York: Paulist Press.

15. Boyea, E. (1987). The National Catholic Welfare Conference: An Experience in Episcopal Leadership, 1935-1945. Ph.D. diss. Catholic University of America.

16. Brodie, Th. (2018). German Catholicism at War, 1939-1945. Oxford.

17. Bureau of the Census (1941). Religious Bodies 1936: Selected Statistics. Washington D.C.

18. Carey, P. W. (2004). Catholics in America. A History. Westport.

19. Carroll, W. (1942). We're in This with Russia. Boston: Houghton Mifflin.

20. Chamedes, G. (2019). A Twentieth-Century Crusade: The Vatican's Battle to Remake Christian Europe. Cambridge MA.

21. Doino, W. Jr. (2004). An Annotated Bibliography of Works on Pius XII, the Second World War and the Holocaust. The Pius War: Responses to the Critics of Pius XII. Ed. Bottum, J. and Dalin, D. Lanham, 97-280.

22. Edwards, B. (2013). The Godless Congress of 1938: Christian Fears about Communism in Great Britain. Journal of Religious History, 37, 1-19.

23. Epple, M. (2001). American Crusader: Bishop Fulton J. Sheen's Campaign against Germany. Ph.D. diss. University of Akron.

${ }^{121}$ For a recent overview of the literature see: Feldkamp, M. (2018). Pius XII. Ein Papst für Deutschland, Europa und die Welt. Aachen. 
24. Farney, K. D. (2016). Golden Mouths, Ethereal Pulpits: The Remarkable Radio Success of Reverend Walter A. Maier, Ph.D. and Monsignor Fulton J. Sheen, Ph.D. Ph.D. diss., University of Notre Dame.

25. Feldkamp, M. (2018). Pius XII. Ein Papst für Deutschland, Europa und die Welt. Aachen.

26. Father Stanislaus Orlemanski at News Conference (Available: https://www.gettyimages.com/detail/video/father-stanislausorlemanski-at-news-conference-exterior-news-footage/504408159).

27. Fogarty, G. (2003). Roosevelt and the American Catholic Hierarchy. FDR, the Vatican, and the Roman Catholic Church in America, 1933-1945. ed. David Woolner and Richard Kurial. New York: Palgrave Macmillan. 11-43.

28. Fogarty, G. (1985). The Vatican and the American Hierarchy from 1870 to 1965 . Wilmington.

29. Frank, R. (1992). Prelude to the Cold War: American Catholics and Communism. Journal of Church and State, 34, 39-56.

30. Freeze, G. L. (2020). The American Catholic Press: Religious NEP, Repression, and Laicization (1925-1939). Новая и новейшая история, 64(6), 121-139.

31. Graham, R. (1996). The Vatican and Communism during World War. San Francisco.

32. Gribble, R. (2008). Roman Catholicism and U. S. Foreign Policy, 1919-1935: A Clash of Policies. Journal of Church and State, 50 73-99.

33. Hayden, Sh. (1944). Foreign Policy of the Vatican. Foreign Policy Reports, 19(21), 277-288.

34. Hlond, A. (1941). The Persecution of the Catholic Church in German Occupied Territories. New York.

35. Huber, R. M. (1952). Our Bishops Speak. Milwaukee.

36. Johnson, W. (2020). Blood Libel and the Pius War. Journal of Religious and Theological Information, 19, 57-69.

37. Kirby, D. (2013). The Religious Cold War. Oxford Handbook of the Cold War. Ed. R. Immerman and Peter Goedde. Oxford, 540-564.

38. Kösters, Ch. (2018). Catholics in the Third Reich: An Introduction to the Scholarship and Research History. Catholics and the Third Reich. Boston. 37-60.

39. Levack, A. P. (1974). Virgilio Scattolini, the Prince of Vatican Misinformers. Catholic Historical Review, 59, 719-735.

40. Massa, M. (2003). Anti-Catholicism in America: The Last Acceptable Prejudice. New York.

41. McNamara, P. (2005). Edmund A. Walsh, S. J., and the Politics of American Catholic Anticommunism. New York.

42. McNamara, P. (2006). Russia, Rome, and Recognition: American Catholics and Anticommunsim in the 1920s. U. S. Catholic Historian, 24, 71-88.

43. Moreno, L. (1999). The National Catholic Welfare Conference and Catholic Americanism, 1919-1966. Ph.D. diss. University of Maryland, 75.

44. National Catholic Welfare Council (1943). The Nazi War against the Catholic Church. Washington, DC.

45. Pastoral Letters of the United States Catholic Bishops (1984). Nolan, H., ed. 4 vols. Washington.

46. Passelecq, G. and Suchesky, B. (1997). The Hidden Encyclical of Pius XI. New York.

47. Powers, R. G. (1995). Not without Honor; the History of American Anticommunism. New York: Free Press.

48. Wider den Rassismus (2001). Rauscher, A., ed. Paderborn.

49. Record of a Conversation between I. V. Stalin and the Roman Catholic Priest Stanislaus Orlemanski (Available: https:// digitalarchive.wilsoncenter.org/document/123130).

50. Roulin, S., van Dongen L. and Scott-Smith G. (2014). Transnational Anticommunism and the Cold War: Agents, Activities, Networks. New York.

51. Sanchez, J. (2002). Pius XII and the Holocaust: Understanding the Controversy. Washington, DC.

52. Die Briefe Pius XII an die deutschen Bischöfe 1939-1944. (1966). Schneider, B., Blet, P., and Martini, A., Eds. Mainz.

53. Sharkey, D. (1944). White Smoke over the Vatican. Milwaukee: Bruce Publishing Co.

54. Sirgiovanni, G. (1990). An Undercurrent of Suspicion: Anti-Communism and Anti-Soviet Opinion in World War II America. New Brunswick.

55. Stehle, H. (1981). Eastern Politics of the Vatican 1917-1979. Athens, Ohio.

56. Wartime Correspondence between President Roosevelt and Pope Pius XII (1947). Taylor, M., ed. New York.

57. Inside the Vatican of Pius XII; the Memoirs of an American Diplomat during World War II (2004). Tillmann, H., ed. New York.

58. European Anti-Catholicism in Comparative and Transnational Perspective (2013). Werner, Y. and Harvard, J., eds. Amsterdam.

59. Wolf, H. (2009). Papst Pius XII. und die Juden. Theologische Revue, 105(4), 265-280.

60. Zugger, C. L. (2001). The Forgotten: Catholics of the Soviet Empire from Lenin through Stalin. Syracuse. 


\section{References}

1. Vasilyeva, O. Yu. (2001). The Russian Orthodox Church and the Policy of the Soviet State in 1943-1948. M.

2. The Russian Orthodox Church during the Great Patriotic War of 1941-1945 (2009). Vasilyeva, O. Yu., Kudryavtsev, I. I., Lykova, L. A., ed. Collection of documents. M.

3. Recording of the conversation of I. V. Stalin with the priest of St. Orleans (1997). Eastern Europe in the documents of the Russian Archives, 1944-1953. Editor: G. P. Murashko (ed.), etc. Novosibirsk. 36-42.

4. Odintsov, M. I. (2005). Power and religion during the war. M.

5. Tokareva, E. S. (2020). Edmund Walsh, Vatican Plans and Russian Reality 1922-1923. Russian History, (4), 188-204.

6. Tokareva, E. S. (2021). The Adventures of a Jesuit in Russia: How the Soviet government fought with fr. Edmund Walsh (19221923). Electronic scientific and educational journal "History", 12, Issue 8 (106) [Electronic resource].

7. Firsov, S. Stalin's Concordat. Nezavisimaya Gazeta, September 3, 2003. Available: https://www.ng.ru/ng_religii/2003-09-03/6 konkordat.html. (accessed: 10 July 2021).

8. Shkarovsky, M. V. (1999). The Russian Orthodox Church under Stalin and Khrushchev. M.

9. Ehrenburg, I. (1945). The tale of the white bull. Pravda, 25.III.1945..

10. Actes es documents du Saint-Siège relatifs à la seconde guerre mondiale [hereafter ADDS]. (1969). Ed. Blet, P., Graham, R. Martini, A., Schneider, B. 12 vols. Vatican City, 1965-1981. 5.

11. Alvarez, D. (2002). Spies in the Vatican. Espionage \& Intrigue from Napoleon to Holocaust. Lawrence, Kansas.

12. Alvarez, D. and Graham R. (1997). Nothing Sacred: Nazi Espionage against the Vatican, 1939-1945. London: Frank Cass.

13. Barone, M. (2003). Franklin D. Roosevelt: A Protestant Patrician in a Catholic Party. FDR, the Vatican, and the Roman Catholic Church in America, 1933-1945. ed. David Woolner and Richard Kurial. New York. 3-10.

14. Blet, P. (1997). Pius XII and the Second World War. According to the Archives of the Vatican. New York: Paulist Press.

15. Boyea, E. (1987). The National Catholic Welfare Conference: An Experience in Episcopal Leadership, 1935-1945. Ph.D. diss. Catholic University of America.

16. Brodie, Th. (2018). German Catholicism at War, 1939-1945. Oxford.

17. Bureau of the Census (1941). Religious Bodies 1936: Selected Statistics. Washington D.C

18. Carey, P. W. (2004). Catholics in America. A History. Westport.

19. Carroll, W. (1942). We're in This with Russia. Boston: Houghton Mifflin.

20. Chamedes, G. (2019). A Twentieth-Century Crusade: The Vatican's Battle to Remake Christian Europe. Cambridge MA.

21. Doino, W. Jr. (2004). An Annotated Bibliography of Works on Pius XII, the Second World War and the Holocaust. The Pius War: Responses to the Critics of Pius XII. Ed. Bottum, J. and Dalin, D. Lanham, 97-280.

22. Edwards, B. (2013). The Godless Congress of 1938: Christian Fears about Communism in Great Britain. Journal of Religious History, 37, 1-19.

23. Epple, M. (2001). American Crusader: Bishop Fulton J. Sheen's Campaign against Germany. Ph.D. diss. University of Akron.

24. Farney, K. D. (2016). Golden Mouths, Ethereal Pulpits: The Remarkable Radio Success of Reverend Walter A. Maier, Ph.D. and Monsignor Fulton J. Sheen, Ph.D. Ph.D. diss., University of Notre Dame.

25. Feldkamp, M. (2018). Pius XII. Ein Papst für Deutschland, Europa und die Welt. Aachen.

26. Father Stanislaus Orlemanski at News Conference (Available: https://www.gettyimages.com/detail/video/father-stanislausorlemanski-at-news-conference-exterior-news-footage/504408159).

27. Fogarty, G. (2003). Roosevelt and the American Catholic Hierarchy. FDR, the Vatican, and the Roman Catholic Church in America, 1933-1945. ed. David Woolner and Richard Kurial. New York: Palgrave Macmillan. 11-43.

28. Fogarty, G. (1985). The Vatican and the American Hierarchy from 1870 to 1965 . Wilmington.

29. Frank, R. (1992). Prelude to the Cold War: American Catholics and Communism. Journal of Church and State, 34, 39-56.

30. Freeze, G. L. (2020). The American Catholic Press: Religious NEP, Repression, and Laicization (1925-1939). Новая и новейшая история, 64(6), 121-139.

31. Graham, R. (1996). The Vatican and Communism during World War. San Francisco.

32. Gribble, R. (2008). Roman Catholicism and U. S. Foreign Policy, 1919-1935: A Clash of Policies. Journal of Church and State, 50 , 73-99.

33. Hayden, Sh. (1944). Foreign Policy of the Vatican. Foreign Policy Reports, 19(21), 277-288.

34. Hlond, A. (1941). The Persecution of the Catholic Church in German Occupied Territories. New York.

35. Huber, R. M. (1952). Our Bishops Speak. Milwaukee.

36. Johnson, W. (2020). Blood Libel and the Pius War. Journal of Religious and Theological Information, 19, 57-69.

37. Kirby, D. (2013). The Religious Cold War. Oxford Handbook of the Cold War. Ed. R. Immerman and Peter Goedde. Oxford, 540-564.

38. Kösters, Ch. (2018). Catholics in the Third Reich: An Introduction to the Scholarship and Research History. Catholics and the Third Reich. Boston. 37-60.

39. Levack, A. P. (1974). Virgilio Scattolini, the Prince of Vatican Misinformers. Catholic Historical Review, 59, 719-735.

40. Massa, M. (2003). Anti-Catholicism in America: The Last Acceptable Prejudice. New York.

41. McNamara, P. (2005). Edmund A. Walsh, S. J., and the Politics of American Catholic Anticommunism. New York.

42. McNamara, P. (2006). Russia, Rome, and Recognition: American Catholics and Anticommunsim in the 1920s. U. S. Catholic Historian, 24, 71-88.

43. Moreno, L. (1999). The National Catholic Welfare Conference and Catholic Americanism, 1919-1966. Ph.D. diss. University of Maryland, 75 . 
44. National Catholic Welfare Council (1943). The Nazi War against the Catholic Church. Washington, DC.

45. Pastoral Letters of the United States Catholic Bishops (1984). Nolan, H., ed. 4 vols. Washington.

46. Passelecq, G. and Suchesky, B. (1997). The Hidden Encyclical of Pius XI. New York.

47. Powers, R. G. (1995). Not without Honor; the History of American Anticommunism. New York: Free Press.

48. Wider den Rasismus (2001). Rauscher, A., ed. Paderborn.

49. Record of a Conversation between I. V. Stalin and the Roman Catholic Priest Stanislaus Orlemanski (Available: https:// digitalarchive.wilsoncenter.org/document/123130).

50. Roulin, S., van Dongen L. and Scott-Smith G. (2014). Transnational Anticommunism and the Cold War: Agents, Activities, Networks. New York.

51. Sanchez, J. (2002). Pius XII and the Holocaust: Understanding the Controversy. Washington, DC.

52. Die Briefe Pius XII an die deutschen Bischöfe 1939-1944. (1966). Schneider, B., Blet, P., and Martini, A., Eds. Mainz.

53. Sharkey, D. (1944). White Smoke over the Vatican. Milwaukee: Bruce Publishing Co.

54. Sirgiovanni, G. (1990). An Undercurrent of Suspicion: Anti-Communism and Anti-Soviet Opinion in World War Il America. New Brunswick.

55. Stehle, H. (1981). Eastern Politics of the Vatican 1917-1979. Athens, Ohio.

56. Wartime Correspondence between President Roosevelt and Pope Pius XII (1947). Taylor, M., ed. New York.

57. Inside the Vatican of Pius XII; the Memoirs of an American Diplomat during World War II (2004). Tillmann, H., ed. New York.

58. European Anti-Catholicism in Comparative and Transnational Perspective (2013). Werner, Y. and Harvard, J., eds. Amsterdam.

59. Wolf, H. (2009). Papst Pius XII. und die Juden. Theologische Revue, 105(4), 265-280.

60. Zugger, C. L. (2001). The Forgotten: Catholics of the Soviet Empire from Lenin through Stalin. Syracuse. 